\title{
THE ASSOCIATION OF EMPLOYMENT STATUS AND INTERNET ACCESS WITH NATIONAL HEALTH INSURANCE MEMBERSHIP
}

\author{
Lely Khulafa'ur Rosidah, Rahma Novita Asdary \\ Academy of Midwivery Dharma Husada Kediri, East Java, Indonesia
}

\begin{abstract}
Background: Many low- and middle-income countries are reforming their health financing mechanisms as part of broader strategies to achieve universal health coverage (UHC). This study aimed to determine the effect of employment status and internet access on national health insurance membership.

Subjects and Method: This was a cross-sectional study using secondary data of the Indonesian Demographic and Health Survey (IDHS) 2017. A total of 5,429 pregnant women was included in this study. The dependent variable was national health insurance membership. The independent variables were employment status and internet access. The data were analyzed by logistic regression.

Results: Employment $(\mathrm{aOR}=2.34 ; 95 \% \mathrm{CI}=1.74$ to 3.16$)$ and internet access (aOR=1.46; $95 \% \mathrm{CI}=1.09$ to 1.97 ) were significantly associated with national health insurance membership.

Conclusion: Employment and internet access are significantly associated with national health insurance membership.
\end{abstract}

Keywords: employment, internet access, national health insurance

\section{Correspondence:}

Lely Khulafa'ur Rosidah. Academy of Midwivery Dharma Husada. Jl Penanggungan No 41 A, Kediri, East Java, Indonesia. Email: lely_khulafaur@akbiddharmahusada-kdr.ac.id. Mobile: +6285664425144 . 